\title{
Evaluation of Radon Concentration in Indoor Air and Groundwater in Shahjahanpur, Uttar Pradesh, India
}

\author{
Anil Kumar ${ }^{1}$ Prachi $^{2}$, R B S Rawat ${ }^{3}$, V K Sharma ${ }^{4}$ \\ ${ }^{\mathbf{1}}$ Department of Physics, S. S. (PG) College, Shahjahanpur, Uttar Pradesh, India \\ ${ }^{2,4}$ Department of Physics, K. G.K. College, Moradabad, Uttar Pradesh, India \\ ${ }^{3}$ Department of Physics, M S (P.G.) College, Saharanpur, Uttar Pradesh, India
}

\begin{abstract}
Radon is a product of the natural radioactive decay of uranium, which occurs naturally in the earth's crust, to radium and then to radon. As radium decays, radon is formed and is released into small air or water-containing pores between soil and rock particles. If this occurs near the soil surface, the radon may be released to ambient air. Radon may also be released into groundwater. If this groundwater reaches the surface, most of the radon gas will quickly be released to ambient air, but small amounts may remain in the water. Evaluation of radon concentration in ground water in Shahjahanpur city of Uttar Pradesh has been carried out using Lucas scintillation cell. Radon concentration was also evaluated in indoor air using solid state nuclear track detector (SSNTD) based twin cup dosimeter technique. Radon concentration was found vary from $9 \mathrm{~Bq} / \mathrm{m}^{3}$ to 78 with an overall average of $31 \mathrm{~Bq} / \mathrm{m}^{3}$. Radon concentration in indoor air varies in summer season from $9 \mathrm{~Bq} / \mathrm{m}^{3}$ to $34 \mathrm{~Bq} / \mathrm{m}^{3}$ with an average of $19 \mathrm{~Bq} / \mathrm{m}^{3}$, during rainy season radon concentration varies from $15 \mathrm{~Bq} / \mathrm{m}^{3}$ to $48 \mathrm{~Bq} / \mathrm{m}^{3}$ with an average of $29 \mathrm{~Bq} / \mathrm{m}^{3}$, during winter season radon concentration varies from 27 $\mathrm{Bq} / \mathrm{m}^{3}$ to $78 \mathrm{~Bq} / \mathrm{m}^{3}$ with an average of $46 \mathrm{~Bq} / \mathrm{m}^{3}$ and during autumn it varies from $16 \mathrm{~Bq} / \mathrm{m}^{3}$ to $48 \mathrm{~Bq} / \mathrm{m}^{3}$ with an average of $29 \mathrm{~Bq} / \mathrm{m}^{3}$. Radon concentration in ground water varies from $3 \mathrm{~Bq} / \mathrm{l}$ to $25 \mathrm{~Bq} / \mathrm{l}$ with an overall average of $12 \mathrm{~Bq} / \mathrm{l}$.
\end{abstract}

Keywords: Radon, groundwater, Lucas cell, Indoor air

\section{Introduction}

Radon is a colorless, odorless gas and radioactive by product of radium. It has half life of 3.825 days. It is like carbon-14 gas, is completely natural. Over the course of several days, a radon atom becomes a lead atom. It is produced as a result of $\alpha$-decay of radium. It is the most harmful gas present in atmosphere. It is present in atmosphere, environment, soil, ground, water, oil and gas deposits, indoor and outdoor. Since it has half life of 3.8 days and therefore has a much better chance of escaping from material in which it was formed. Hence it reaches the indoor environment as a soil gas from the ground and also from walls, ceilings etc. and other building materials used in construction of human dwellings. In some countries, the radiation dose to man caused by inhaled radon daughters constitutes more than $50 \%$ of the total dose (UNSCEAR; 2000, Lubin; 1993). The groundwater radon concentration is expected to reflect not only in chemical form but also in structural properties of rock in an aquifer (Y Sasaki; 1995). The second most important contributor to outer radon is emanation from ground water sources. Ground water in contact with rustle rock penetrates into the pores and voids present in the rocks and soils and dissolves radon that emanates into these spaces following ${ }^{226} \mathrm{Ra}$ decay. Radon is very soluble in water (Misdaq etal.2000)

In most cases, the movement of radon in water is governed by water transport rather than diffusion. Various investigation is have been made to correlate ${ }^{222} \mathrm{Rn}$ concentration in water supplies with indoor radon levels in typical homes (Lamresh, J.R., 1983).

\section{Experimental Methods}

The measurements of radon in indoor air and ground water have been carried out by using environmental radiation dosimeter and Lucas scintillation cell respectively. Brief descriptions of these techniques are as follows:

\section{Radon measurement in indoor air}

Concentration of radon and thoron were measured by using LR-115 Type II plastic track detector. Three small pieces of detector films of size $2.5 \mathrm{~cm} \times 2.5 \mathrm{~cm}$ were fixed in a twin chamber radon/thoron dosimeter having three different modes. The bare mode gives the values of radon, thoron and their progeny concentrations while the filter and membrane modes records the values due to radon, thoron and pure radon gas, respectively. The dosimeters were suspended inside the house at a height of about two meters from the ground floor. After an exposure time of three months, the detector films were removed etched with $10 \% \mathrm{NaOH}$ solution for one hour at a bath temperature of $60^{\circ} \mathrm{C}$. The bulk etching rate is about $4 \mu \mathrm{m} / \mathrm{h}$. The detector films are then washed in distilled water. After washing, the detectors are air dried in dust free environment The detectors, having a residual thickness of $8 \mu \mathrm{m}$ after etching, are peeled off from their plastic bases and the tracks are registered with spark counter. The recorded track density was then converted in the $\mathrm{Bq} / \mathrm{m}^{3}$ by using an appropriate calibration factor (Ramola et. al., 1996). This measurement was repeated on a time integrated four quarterly cycles to cover all the four seasons of a calendar year. 


\section{International Journal of Science and Research (IJSR) \\ ISSN (Online): 2319-7064}

Index Copernicus Value (2013): 6.14 | Impact Factor (2014): 5.611

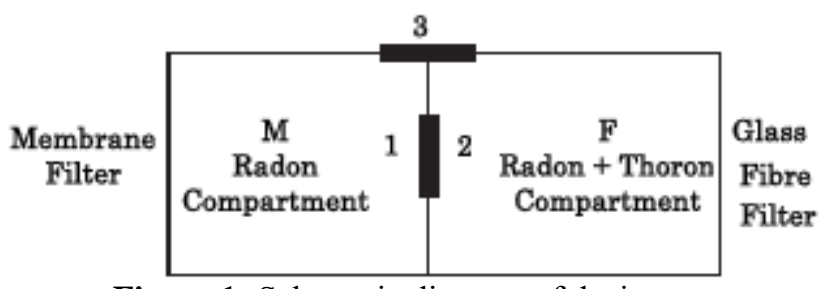

Figure 1: Schematic diagram of dosimeter

\section{Radon measurement in groundwater}

For the measurements of radon in ground water, a radon tight reagent bottle of one liter capacity holds $750 \mathrm{ml}$ water was taken. The water samples from the ground water were collected. The sample bottle was connected in a closed circuit with Lucas Cell, hand operated rubber pump through a bubbler. The air was circulated in a closed circuit for a period of 15 min until the radon forms a uniform mixture with the air. After sampling the Lucas cell connected to detector and resulting counts were recorded. The observed counts then converted to $\mathrm{Bq} / \mathrm{l}$ by using the appropriate calibration factor.

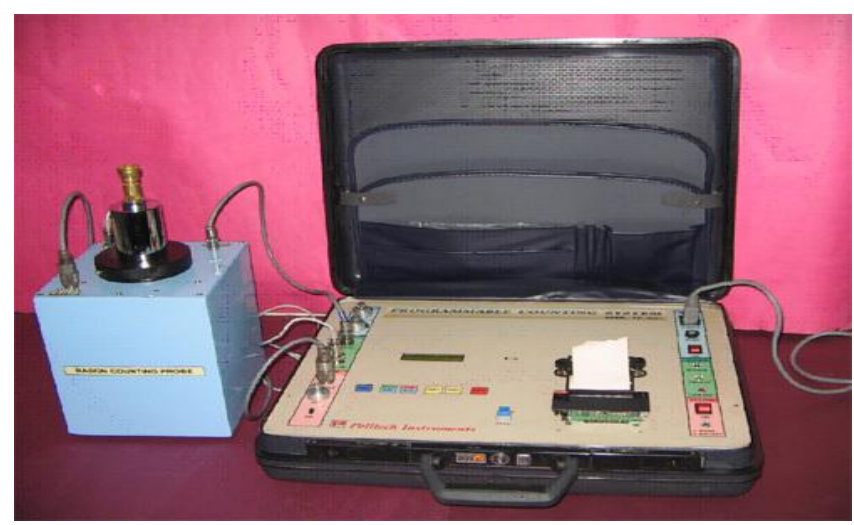

Figure 2: Emanometer and dectector with lucas cell

\section{Results and Discussion}

The measured values of radon concentrations in indoor air and groundwater in different seasons are shown in Table 1 $\&$ Table 2 respectively.

Table 1: Radon concentration $\left(\mathrm{Bq} / \mathrm{m}^{3}\right)$ in indoor air.

\begin{tabular}{|c|c|c|c|c|c|c|c|c|c|c|c|c|}
\hline Location & \multicolumn{3}{|c|}{ Summer } & \multicolumn{4}{c|}{ Rainy } & \multicolumn{3}{c|}{ Winter } & \multicolumn{3}{c|}{ Autumn } \\
\hline & Min & Max & Mean & Min & Max & Mean & Min & Max & Mean & Min & Max & Mean \\
\hline Ajeej Ganj & 12 & 27 & 20 & 22 & 37 & 28 & 43 & 67 & 56 & 16 & 30 & 25 \\
\hline Nevada indepur & 19 & 31 & 26 & 15 & 39 & 27 & 32 & 48 & 39 & 24 & 38 & 31 \\
\hline Lodhipur & 11 & 24 & 18 & 17 & 27 & 22 & 27 & 75 & 54 & 27 & 48 & 35 \\
\hline Bahadur Ganj & 13 & 34 & 22 & 25 & 42 & 34 & 32 & 47 & 40 & 25 & 30 & 27 \\
\hline Babujai & 9 & 28 & 17 & 25 & 37 & 32 & 33 & 45 & 38 & 21 & 29 & 25 \\
\hline Khalil Sarqi & 9 & 17 & 13 & 26 & 48 & 38 & 36 & 68 & 52 & 26 & 39 & 34 \\
\hline Keruganj & 16 & 33 & 24 & 20 & 34 & 26 & 29 & 47 & 37 & 25 & 37 & 32 \\
\hline Jalal Nagar & 14 & 28 & 21 & 28 & 36 & 31 & 29 & 47 & 38 & 24 & 34 & 29 \\
\hline Kachcha Katra & 11 & 23 & 16 & 16 & 34 & 27 & 35 & 62 & 48.4 & 17 & 29 & 23.6 \\
\hline Hathaura & 16 & 26 & 21 & 22 & 34 & 28 & 50 & 78 & 62 & 25 & 38 & 32 \\
\hline Anandpuram Colony & 10 & 15 & 12 & 19 & 32 & 26 & 40 & 49 & 45 & 26 & 30 & 28 \\
\hline
\end{tabular}

Table 2: Radon concentration $(\mathrm{Bq} / \mathrm{l})$ in groundwater.

\begin{tabular}{|c|c|c|c|c|c|c|c|c|c|c|c|c|}
\hline Location & \multicolumn{3}{|c|}{ Summer } & \multicolumn{3}{c|}{ Rainy } & \multicolumn{3}{c|}{ Winter } & \multicolumn{3}{c|}{ Autumn } \\
\hline & Min & Max & Mean & Min & Max & Mean & Min & Max & Mean & Min & Max & Mean \\
\hline Ajeej Ganj & 9 & 19 & 15 & 13 & 22 & 17 & 7 & 14 & 11 & 7 & 18 & 13 \\
\hline Nevada indepur & 8 & 14 & 10 & 4 & 25 & 18 & 9 & 13 & 11 & 9 & 14 & 11 \\
\hline Lodhipur & 10 & 17 & 12 & 13 & 19 & 17 & 9 & 16 & 12 & 4 & 12 & 10 \\
\hline Bahadur Ganj & 7 & 11 & 9 & 9 & 17 & 12 & 5 & 13 & 9 & 8 & 12 & 10 \\
\hline Babujai & 5 & 12 & 10 & 9 & 16 & 12 & 7 & 12 & 10 & 3 & 12 & 8 \\
\hline Khalil Sarqi & 9 & 19 & 14 & 14 & 17 & 15 & 10 & 13 & 12 & 7 & 12 & 10 \\
\hline Keruganj & 9 & 20 & 14 & 16 & 21 & 19 & 11 & 13 & 12 & 6 & 15 & 11 \\
\hline Jalal Nagar & 9 & 14 & 10 & 8 & 13 & 11 & 8 & 11 & 10 & 7 & 15 & 11 \\
\hline Kachcha Katra & 8 & 12 & 11 & 13 & 18 & 15 & 5 & 11 & 9 & 9 & 15 & 11 \\
\hline Hathaura & 9 & 14 & 11 & 10 & 24 & 16 & 7 & 13 & 10 & 8 & 11 & 9 \\
\hline Anandpuram Colony & 12 & 18 & 15 & 11 & 17 & 14 & 3 & 16 & 10 & 4 & 14 & 10 \\
\hline
\end{tabular}


International Journal of Science and Research (IJSR)

ISSN (Online): 2319-7064

Index Copernicus Value (2013): 6.14 | Impact Factor (2014): 5.611

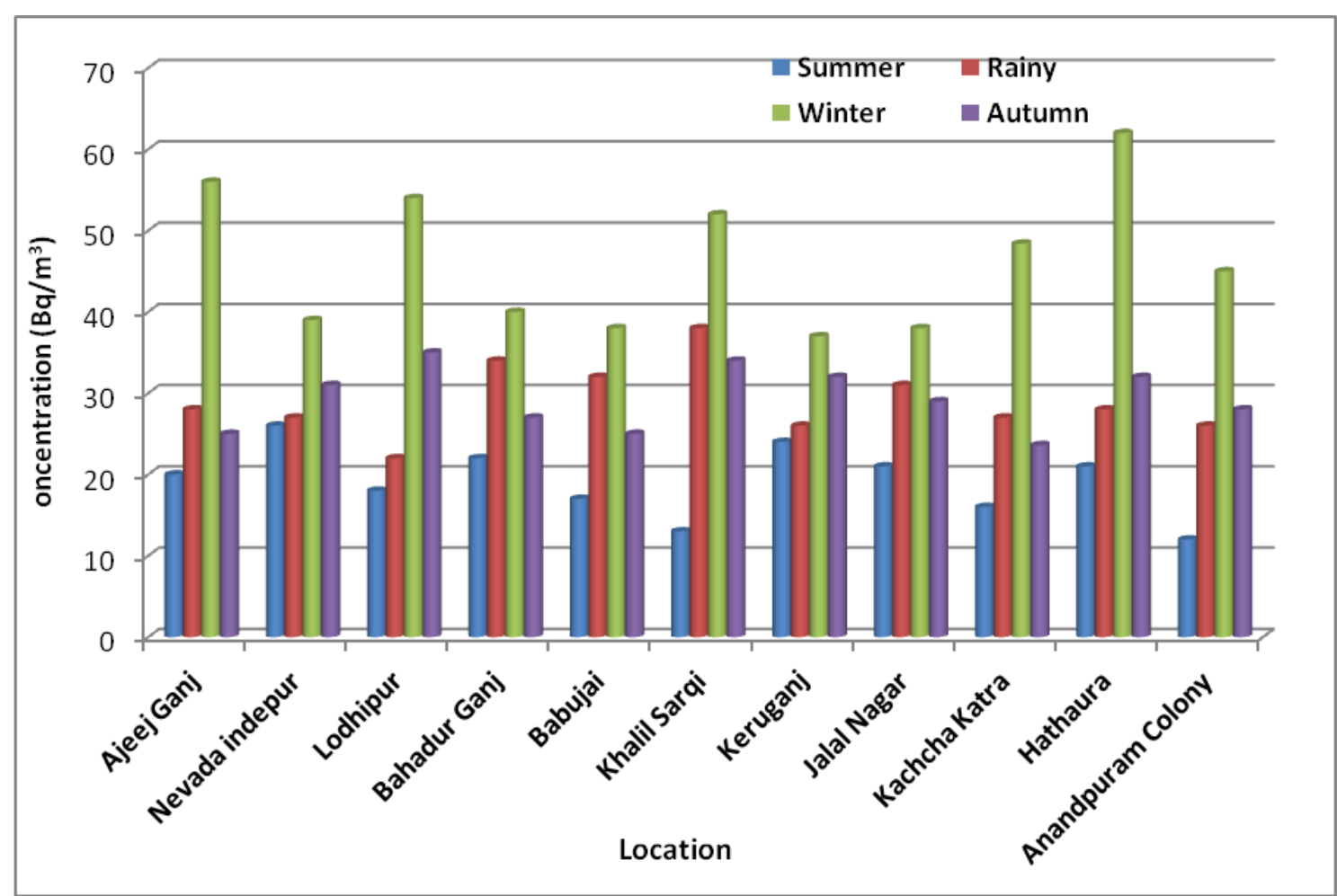

Figure 3: Seasonal variation of radon concentration in indoor air.

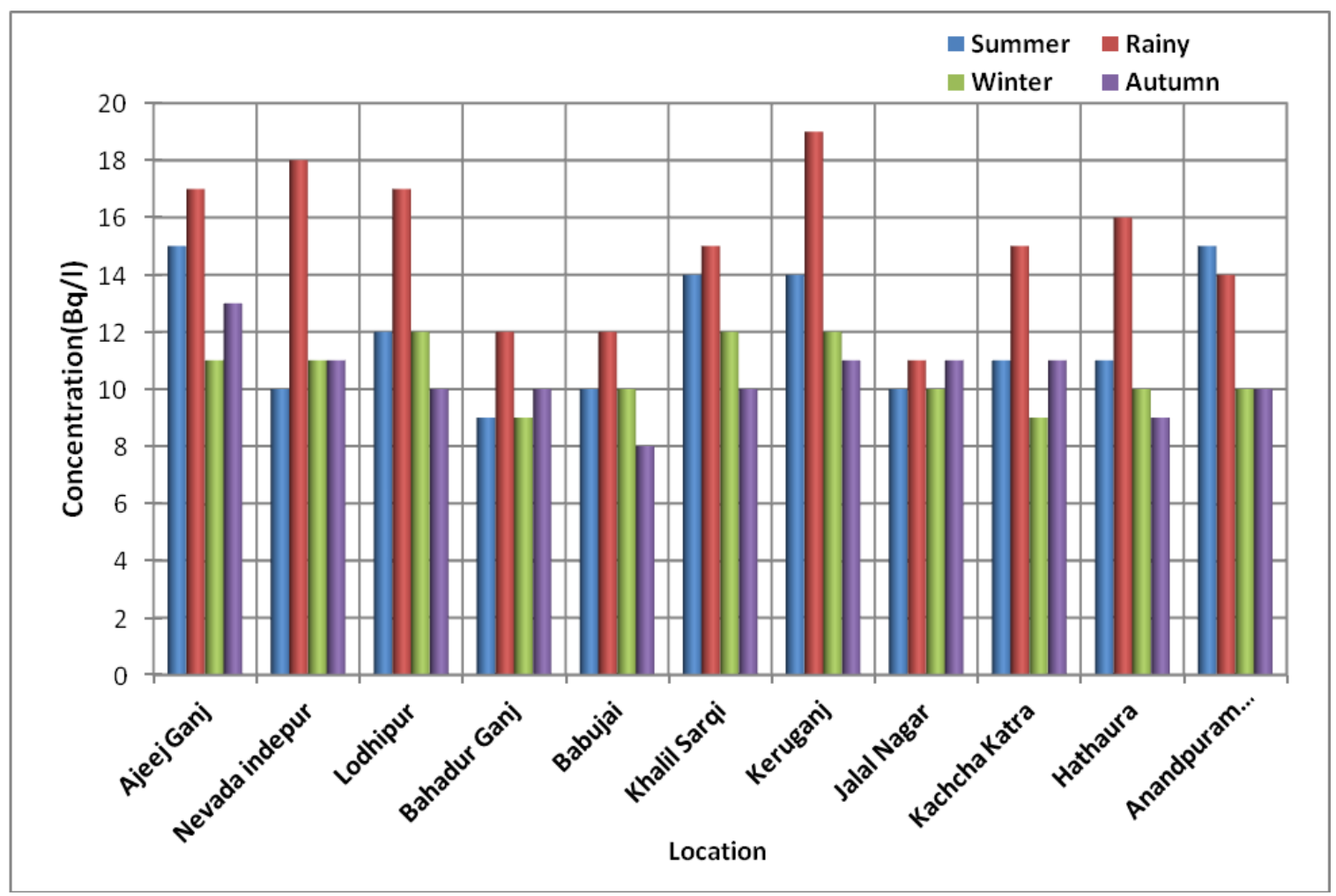

Figure 3: Seasonal variation of radon concentration in groundwater.

The radon concentration in indoor air was found to vary from $9 \mathrm{~Bq} / \mathrm{m}^{3}$ to $78 \mathrm{~Bq} / \mathrm{m}^{3}$, with an overall average of 31 $\mathrm{Bq} / \mathrm{m}^{3}$, while in groundwater it was found to vary from 3 $\mathrm{Bq} / 1$ to $25 \mathrm{~Bq} / \mathrm{l}$ with an average of $12 \mathrm{~Bq} / \mathrm{l}$. Radon concentration in indoor air varies in summer season from 9 $\mathrm{Bq} / \mathrm{m}^{3}$ to $34 \mathrm{~Bq} / \mathrm{m}^{3}$ with an average of $19 \mathrm{~Bq} / \mathrm{m}^{3}$, during rainy season radon concentration varies from $15 \mathrm{~Bq} / \mathrm{m}^{3}$ to 48 $\mathrm{Bq} / \mathrm{m}^{3}$ with an average of $29 \mathrm{~Bq} / \mathrm{m}^{3}$, during winter season radon concentration varies from $27 \mathrm{~Bq} / \mathrm{m}^{3}$ to $78 \mathrm{~Bq} / \mathrm{m}^{3}$ with an average of $46 \mathrm{~Bq} / \mathrm{m}^{3}$ and during autumn it varies from 16 $\mathrm{Bq} / \mathrm{m}^{3}$ to $48 \mathrm{~Bq} / \mathrm{m}^{3}$ with an average of $29 \mathrm{~Bq} / \mathrm{m}^{3}$.

Radon concentration in ground water varies from $3 \mathrm{~Bq} / 1$ to $25 \mathrm{~Bq} / 1$ with an overall average of $12 \mathrm{~Bq} / \mathrm{l}$. In summer season the radon concentration in groundwater varies from 5 $\mathrm{Bq} / 1$ to $20 \mathrm{~Bq} / 1$ with an average of $12 \mathrm{~Bq} / \mathrm{l}$, In rainy season radon concentration in groundwater from $4 \mathrm{~Bq} / \mathrm{l}$ to $25 \mathrm{~Bq} / \mathrm{l}$ with an average of $15 \mathrm{~Bq} / \mathrm{l}$, In winter season radon 


\section{International Journal of Science and Research (IJSR) \\ ISSN (Online): 2319-7064}

Index Copernicus Value (2013): 6.14 | Impact Factor (2014): 5.611

concentration in groundwater from $3 \mathrm{~Bq} / 1$ to $16 \mathrm{~Bq} / 1$ with an average of $11 \mathrm{~Bq} / \mathrm{l}$, In autumn season radon concentration in groundwater $3 \mathrm{~Bq} / 1$ to $18 \mathrm{~Bq} / 1$ with an average of $10 \mathrm{~Bq} / 1$.

The concentration of radon in indoor air was found least in summer while highest in winter. This is because, in summer season, the houses remain open for long time which contributes in increasing air exchange rate while in winter; the rooms are remaining closed for long hours decreasing air exchange. In groundwater the radon concentration found least in autumn while highest in rainy.

\section{Conclusions}

Based on the results obtained from the study area, the concentrations of radon vary with the season. The concentrations of radon were measured highest in winter and lowest in summer. Indoor radon concentrations in the study area were found to depend on the building materials, mode of construction of a house, ventilation condition of house, volume of the room and geology of the area concentration. The annual overall average levels of radon in the study area were found well below the action levels set by some different countries and institutions. The observed values of radon concentrations in groundwater for different seasons are comparably lower than internationally recommended safe values 4 to $40 \mathrm{~Bq} / \mathrm{l}$ (UNSCEAR, 1982).

\section{References}

[1] UNSCEAR, Report to the General Assembly United Nations, New York, 1982.

[2] Misdaq M.A.;Merzouki A.; Elabboubi D.; Aitnouh F.; Berrazzouk S.,(2000) Determination of radon equivalent alpha doses in different human organs from water ingestion using SSNTD and Dosi. Compartmental Models. J. Radio analytical and Nuclear Chemistry, 245 (3), 513-520.

[3] Ramola, R.C., Rawat, R.B.S., Kandari, M.S., Ramachandran, T.V., Eappen, K.P. and Subba Ramu, M.C. (1996) Calibration of LR-115 Plastic track detector for environmental radon measurements. Indoor Built Environ. 5, 364-366.

[4] UNSCEAR, Ionizing Radiation Sources and Biological Effects (New York : United Nations) (1982).

[5] UNSCEAR, Sources and Effects of Ionizing Radiation (New York : United Nations) (2000)

[6] J H Lubin and (Jr.) J D Boice J. Nat. Can. Inst. 8949 (1993).

[7] G Igarashi, S Saeki, N Takahata, K Sumikawa, S Tasaka, Y Sasaki, M Takahashi and Y Sano Science 26960 (1995) .

[8] Lamresh J.R., (1993), Introduction to nuclear Engineering, Addison- Wesley Publishing Company. 